\title{
Evaluation of Lecturers in Online Learning during the Covid-19 Pandemic
}

\author{
Erniati $^{1}$, Hastuti ${ }^{2}$, Kasmah $^{3}$, Sitti Hasnah ${ }^{4}$ \\ \{erniati@iainpalu.ac.id ${ }^{1}$, hastuti.baharuddin@uin-alauddin.ac.id ${ }^{2}$, kasmahusman@gmail.com³ \\ sitti.hasnah700831@gmail.com $\left.{ }^{4}\right\}$
}

IAIN Palu, Indonesia ${ }^{1}$, UIN Alauddin Makassar, Indonesia ${ }^{2}$, IAIN Bone, Indonesia ${ }^{3}$, IAIN Palu, Indonesia $^{4}$

\begin{abstract}
Lecturers as the front-line of teaching and learning activity in any campus must always present an interesting and effective online learning model to achieve the best quality of education even in the midst of the Covid-19 outbreak. However, the sudden policy resulted lecturers in experiencing imbalances. Therefore, this study examines the results of the evaluation of lecturers in applying online learning after the government's policy in the pandemic covid-19 with the purpose of analyzing performance result of lecturers during online learning, then mapped the difficulties faced as a consideration for finding solutions in implementing the next online learning. The method used in this research was descriptive qualitative by collecting data from the results of observations on lecturers and survey data from lecturers and students through goggle form as well as data from lecturers' monitoring and evaluation from campus' LPM. From the research results, it was found that the evaluation of lecturers in online learning was less effective. The reason was due to the lack of digital literacy knowledge of lecturers caused by the unpreparedness of applying online learning. The age factors are also one of the cause which caused the lecturers unable to operate IT or digital applications for online learning.
\end{abstract}

Keywords: lecturers' evaluations, online learning, covid-19 pandemic

\section{Introduction}

The policy from Government to implement online learning in the covid-19 pandemic created disruptions and confusions in the Educational system, especially on college campuses due to their unpreparedness in facing distance learning. Lecturers as a main motivator in the learning process was feeling overwhelmed because they are required to adapt quickly from face-to-face curriculum into online learning curriculum that was relatively difficult [1]. The lack of digital literacy, low ability to use IT, lack of understanding in operating online applications, and the age factors are some obstacles faced by lecturers in conducting online learning. According to Konrad Grabinski, some lecturers are reluctant to introduce this form of education, due to lack of experience in using information technology and lack of adequate support from the IT department [2]. In addition, the instability of network access and the inadequate campus infrastructure also caused the teaching and learning process to be hampered and even less effective. In a survey in one of 
university, around $44 \%$ of lecturers use Whatsapp Group in the teaching and learning process, 22\% use Google Classroom, 9\% use Zoom, 8\% use Campus E-Learning, 3\% use Google Meet, and $14 \%$ use others (UINAM monev online, 2020). From this data it proves that most lecturers only use the WAG application for online learning.

Research related to the evaluation of online learning during the Covid-19 pandemic tends to focus on three aspects. First: Application of online learning in universities [3]. Second: evaluation of online learning in universities [4] [6]. Third: analysis of online learning during the WFH period [7], [8] . These studies have not yet explained the specific evaluation emphasized on lecturers in implementing online learning during the Covid-19 pandemic.

This article seeks to fill that gap by analyzing the results of lecturer evaluations in online lectures during the Covid-19 pandemic by answering three questions. First, what are the results of lecturer evaluations in online learning during the Covid-19 pandemic? This question focuses on the results achieved by lecturers during online lectures. Second, what is the response that causes the evaluation results? This question aims to map the difficulties experienced by lecturers during the online learning process. Third, what are the solutions for future online learning? This question is to provide an effective and interesting online learning solutions in the future.

This article is based on the argument that the results of lecturer evaluations in online learning that were applied during the Covid-19 pandemic were classified into two types; effective and less effective results. Effective results were in the form of the creating a fun and efficient online learning environment to boost the spirit and enthusiasm of both students and lecturers to master the technology. The ineffective results of the lecturers' evaluation were in the form of curriculum targets that were not being achieved properly due to inactive learning interactions. The results of the evaluation were motivated by the unpreparedness of the lecturers with the digital learning environment, the low ability and competence in using IT and the age factor of lecturers who were unable to operate several online learning applications.

\section{Literature Review}

\subsection{The Concept of Online Learning in Higher Education}

Online learning, also called distance education, is a teaching and learning process that is carried out remotely through the use of several communication media. Distance education aims to provide higher education services to groups of people who are unable to attend face-to-face or regular education and to expand access and facilitate higher education services in the education and learning process. The special purpose of distance education during the Covid -19 pandemic is to provide higher education for the community from a distance in order to follow the Government's Work from Home (WFH) policy as an effort to prevent the transmission of the Covid-19 virus. Distance education in tertiary institutions is held in various forms, modules, and coverage supported by facilities and services as well as an assessment system that ensures the quality of graduates according to the National Higher Education Standards [9].

The concept of online learning in tertiary institutions according to Tian Betawati [10] was that lecturers must comprehend the character of students to know the 
application to be used accordingly. Lecturers must be innovative and creative in designing online teaching materials. In addition, the interaction between lecturers and students must be active and there should be good feedback. The online lecture system according to [11] was that the lecturing system in universities was developed by the Ministry of Education and Culture of the Republic of Indonesia through the Open and Integrated Indonesian Online Lecture Program (KDITT). KDITT is a program from the government aimed in reaching the students on the national scale.

\subsection{The Effectiveness of Online Learning Concept}

There are several principles for effective online learning according to Tian Betawati, namely proper curriculum, good interaction between learners, using innovative approaches, effective and inclusive methods, formative and summative evaluation, coherent, consistent, transparent, easy-to-operate devices, and also effective in cost [10]. [12] explains that a good online learning flow is the presentation of learning designed in such a way which includes a learning guide, description, a series of digital materials and a series of learning activities that are arranged in deductive-inductive way to becomes an interactive, interesting learning object and to achieve optimal learning quality. The most important thing from this principle is interaction with learners (lecturers and students). Therefore, lecturers as the main motivators must prepare a syllabus that is more suitable for online learning and adapt to the online application that will be used so that there are no difficulties when online lectures take place.

\subsection{Lecturer evaluations improve the quality of education}

The performance of educational personnel, especially lecturers, as the front-line in providing educational services, is a very important issue to be studied in order to maintain and improve the quality of educational services. Great performance from lecturers became one of the keys to improve and maintain quality educational services to society [13]. To measure lecturers' performance results, it is necessary to evaluate in order to predict the design of procedures or implementation design during the implementation stage, provide information to overcome difficulties and as a consideration for overcoming difficulties by offering solutions [4].

\section{Methods}

This study uses qualitative descriptive method, by collecting data through surveys and observations. The survey was carried out to students and lecturers regarding the application of online lectures which lasted approximately 3 months during the Covid-19 pandemic with a research instrument using a questionnaire questions distributed through the goggle form application. Strengthened by the data obtained from the campus LPM on the results of monitoring the evaluation of lecturers in online learning. The data is equipped with self- observation from research lecturers to find out about the online learning system carried out during the Covid-19 pandemic.

The information for this article was obtained from respondents from 3 universities, namely UIN Alauddin Makassar, IAIN Bone, and IAIN Palu. The Respondents for the survey data were 211 students and 63 lecturers, for self-observation data came from 3 lecturers, and supporting data from the results of online monitoring and evaluation were 
from LPM from the 3 colleges. The requested data relates to the five domains that are the main focus of the research, namely: 1) the effectiveness of online learning , 2) applications that are often and easily used in online lectures, 3) obstacles and deficiencies experienced when carrying out online learning, 4 ) Solutions that will be expected to support the realization of effective learning with online lectures.

The data analysis of this research uses the analysis model of Milles, Huberman and Saldana [14], there are three concurrent flows of activity: 1) data condensation, 2) data display, and 3) conclusion drawing / verification. To collect the data, selecting the data from the field, then combine and categorize the data obtained. At the data display stage, the researcher explains the data that has been collected then retrieves the required data. After that, the sorted data would then be interpreted to be the result of the findings after conducting the research.

\section{Results and Discussion}

In accordance to the orientation of the research, this article interpreted the results of the evaluation of lecturers in applying online learning in the covid-19 pandemic, then analyze the difficulties encountered during the online learning process which resulted in the quality of teaching which was less effective, and solutions to optimize the online learning process.

\subsection{Results of lecturer evaluations in online learning during the Covid-19 pandemic}

From the research results it was found that online learning during the Covid-19 pandemic was less effective. Based on the data obtained from the google form survey, 211 respondents from among students 90,5\% answered ineffective. Most of them gave ineffective responses on the grounds that the lecturers only gave material without explanation and feedback, the methods used were less attractive, where students were burdened with assignments, lack on facilities such as cellphones, networks and learning applications (google form student data survey, 2020). While a survey of 63 lecturers 58, $7 \%$ responded less effectively. Most Lecturers gave reasons, such as the lack of preparation in the application of online learning, online curriculum standards is not applicable and adequate, the learning objectives was less understood by the students, limited facilities, and unstable connection (google the data survey form lecturer, 2020). The following is a chart of student and lecturer surveys:

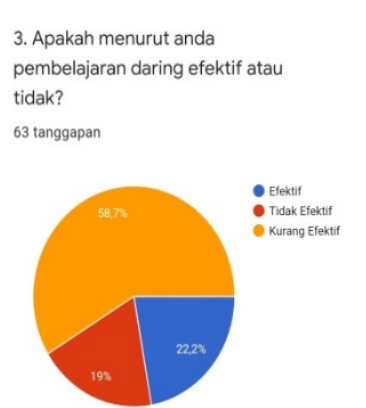

Source: Survey Google Form of Lecturers

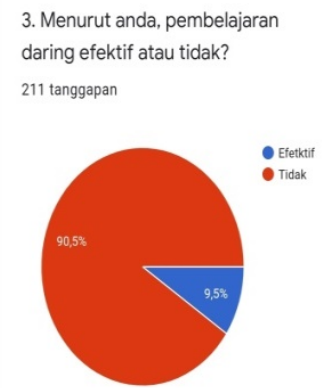

Source: Survey Google Form Students

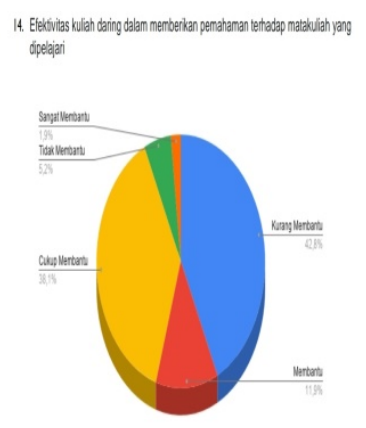

Source: Monitoring Evaluation from LPM IAIN Palu

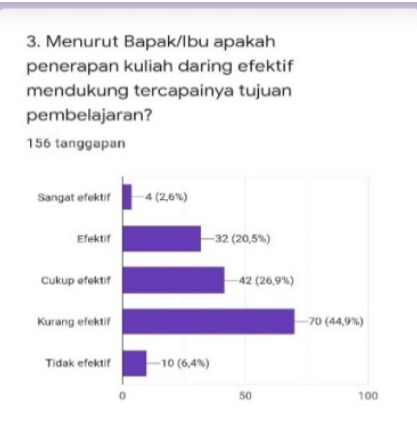

Source: Monitoring Evaluation from LPM IAIN Bone 
From the data above, most students responded less effective because the lecturer only gave material without explanation and feedback, the method used was less attractive, was burdened with assignments, lack of facilities such as cellphones, networks and learning applications. The most of the lecturers gave reasons that there was a lack of preparation in implementing online learning, online curriculum standards were not ready and inadequate, learning objectives could not be understood by students, limited facilities, and unstable connections.

In accordance with the results of self-observations from researchers as lecturers that during the Covid-19 pandemic, learning activities was not optimal. The main reason is due to the sudden change in learning policy without prior preparation, resulting in the learning model used is adjusted with the level of digital literacy skills possessed by both the lecturers and students. The low digital competence gave results to the less effective learning interactions. Delivering the lecture schedule through the WAG, then to start the teaching learning process by filling in the attendance list at the campus e-Learning called Lentera. After that, the researcher as lecturer read the material in the material column, asking questions in the discussion column then conducting discussions via Zoom for about 30 minutes to answer and respond to questions in the existing discussion column in Lentera (Hastuti, UIN Alauddin Makassar, 2020). The limitations in applying some of the features on the platform made the learning environment unvaried, using only limited known features.

Erniati and Kasma responded that lectures conducted during the Covid-19 pandemic used standard applications, namely WAG and Google Clasroom, occasionally used Zoom application in several meetings. Lack of mastery in operating the features in WAG, Google Classroom and Zoom results in a less innovative learning environment. Even though there are several features in the application that are satisfactory in managing online learning to make it interesting and effective (Erniati, IAIN Palu 2020 and Kasma Usman, IAIN Bone 2020).

Based on the data above, it shows that the learning environment was less effective during online lectures during the Covid-19 pandemic because it was dominantly due to lecturers' unpreparedness in facing online learning. Online learning requires technical knowledge to master various features in the application so that is why, it requires innovative and creative effort from lecturers to be able to use these features in processing lecturing materials, answering questions, and discussing. However, the reality in the class is that lecturers' unpreparedness gave results to the unfamiliarity of using online technology to many lecturers. In fact, many of the older lecturers are not literate enough to use digital platforms.

\subsection{The dominant factors causing the lecturers' evaluation results}

\subsubsection{Lecturers' digital literacy}

The application of digital literacy as an interesting alternative to learning using digital sources. It is used as an actual reference to support the process of creative, innovative, and independent learning by utilizing information technology (Tosepu, YA, 2018) during the Covid-19 pandemic. Therefore, lecturers must have the competence to operate technologies to conduct effective online learning. However, urgency in rules forced the occurrence of minimal digital literacy by the lecturer resulting in their inability to operate digital technology and limitations in using varieties of online learning 
applications. Therefore, learning is limited only to provide materials without any explanations and giving independent and group assignments without any feedback. This evidence is supported from the google form survey data for students and lecturers and data from the campus LPM. Below is the chart:

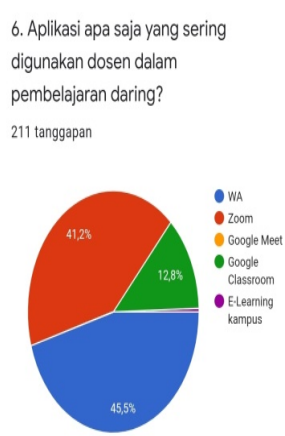

Source: Data Survey by google form of students

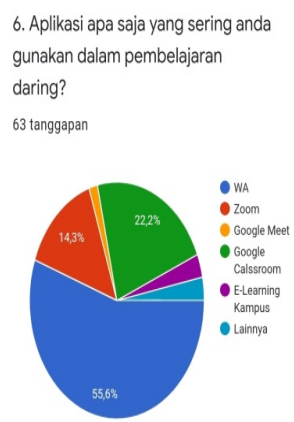

Source: Data Survey by goggle form of lecturers

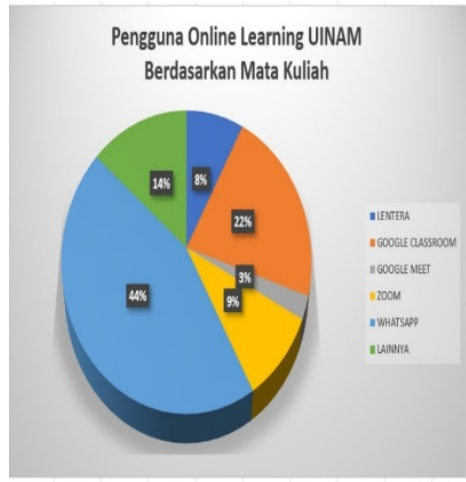

Source: Monitoring Evaluation from LPM UINAM

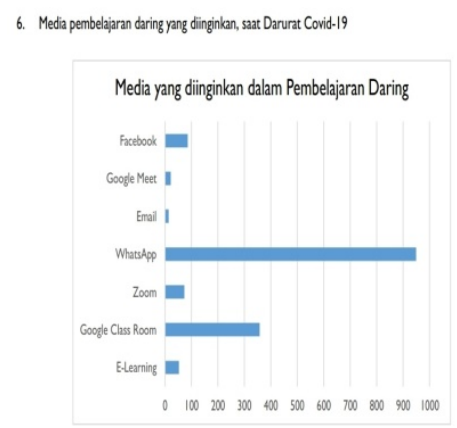

Source: Monitoring Evaluation from LPM IAIN Palu

Student survey data showed that out of 211 students $45.5 \%$ responded applications that are often used in online learning are What Sapp Group (WAG) , 41,2\% used Zoom Applications, and $12.8 \%$ used Google Classroom. In the lecturer survey, $55.6 \%$ of the 63 respondents chose WAG as an application that was often used during the online learning process, $22.2 \%$ used Google Classroom, $14.3 \%$ Zoom, 8\% Campus E-Learning, and $4 \%$ other applications. Data from LPM IAIN Palu found that $81 \%$ used WAG, $34 \%$ used Google Classroom, 12\% Zoom, 6\% Google Meet and E-Learning, 5\% Facebook, 2\% YouTube, E-mail and Messenger, 1\% WebEx, Quizzes and Instagram. And data from LPM UIN Alauddin Makassar shows around $44 \%$ of lecturers use What Sapp Group in the teaching and learning process, $22 \%$ use Google Classroom, $9 \%$ use Zoom, $8 \%$ use Campus ELearning, $3 \%$ use Goggle Meet, and $14 \%$ use other Applications.

From this data, it proves that most of the lecturers only use the WAG application in online learning. WAG is indeed one of the social networking applications that can be used as e-learning [15], but WAG use would not be able to monitor student attendance, provide detailed materials, give assignments or tests to students to the maximum. WAG is the most standard application in online learning. This means that lecturers are not yet used to using other applications as an online learning method.

\subsubsection{The age factors for lecturers}

Other than the lack of digital literacy skills of lecturers, many also pointed that age was also one of the determining factors. This is evidenced from the data from lecturer respondents. 


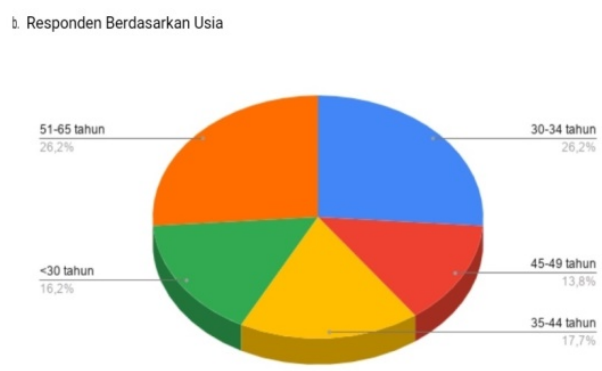

Source: Monitoring Evaluation from LPM

\section{IAIN Palu}

The age factor of the lecturers had an impact on the level of difficulties faced when using online learning media. Senior or older Lecturers did not have the literacy in using digital platform, some even completely incompetent in the use of electronic devices.
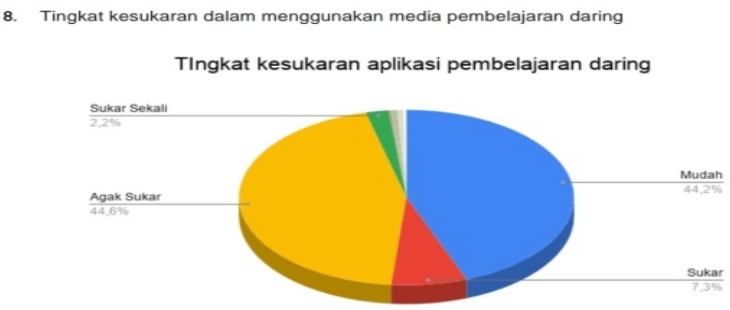

Source: Monitoring Evaluation from LPM IAIN Palu

This data shows that lecturers dominantly has difficulties using online learning applications. It is difficult to operate the application without assistance by someone else in operating the online learning applications. Some even preferred to only give assignments to students on their classes' schedule.

3. Komponen Perkuliahan

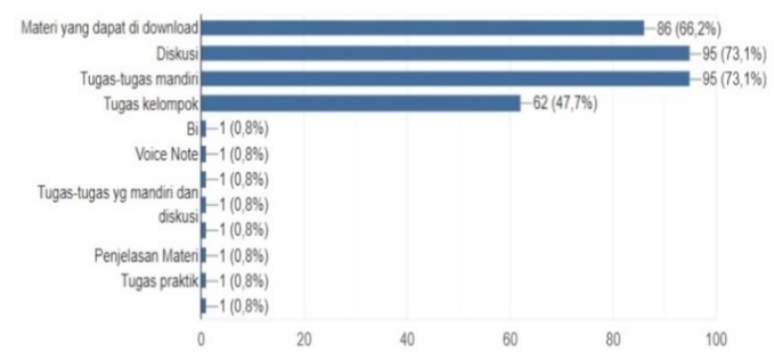

Source: Monitoring Evaluation of Lecturers from LPM Palu 
Based on the data above, about $73.1 \%$ of online lecture methods provide independent assignments to students, $73.1 \%$ of discussions, $66.2 \%$ of downloading materials and $47.7 \%$ of group assignments. This shows that lecturers dominantly gave independent assignments, downloaded material, group assignments and some had discussions. The use of such learning methods caused the students to have less enthusiasm in taking part in lectures, students often feel weary because of the less varied learning methods. This was one of the complaints of students in online learning because of the excessive distributions of assignments from lecturers.

Apart from the excessive distributions of assignments from lecturers, there are several other obstacles to online learning related to the role of lecturers. As the survey data from 211 respondents, students answered that the difficulties were mostly caused by lecturers.

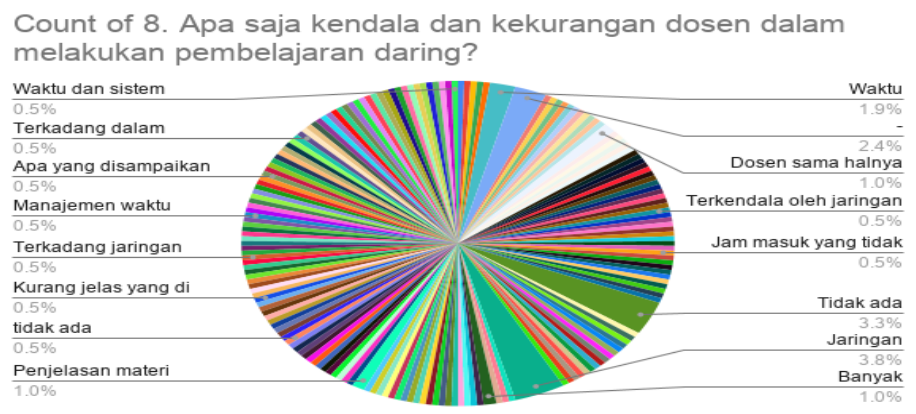

Source: Data Survey by google form of students

From the data above, several difficulties could be mapped as follows; 1) time management, incomprehensible explanations of the materials, 2) lack of network access, and 3 ) less supportive learning system. In accordance, the results of the lecturer data survey with 63 respondents, mostly answered because of bad network access, difficulties in operating the platform, and a lack of online lecture materials.

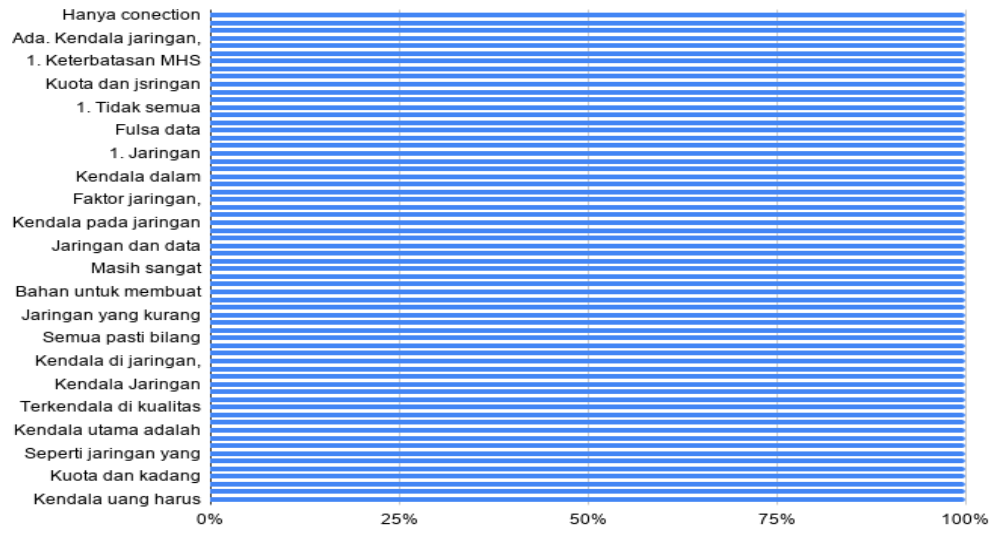

Source: Data Survey by google form of lecturers 


\subsubsection{Solutions For The Application Of Online Learning In The Future}

Based on the two factors above, some solutions have been summarized to support a more interesting and effective online learning. They are:

a. Providing digital literacy training for lecturers to help understand the digital learning system which is the key to the online learning process.

b. Providing training for distance learning curriculum.

c. Completing the campus infrastructure so that the applications used can be similar and structured.

d. If the campus does not provide LMS, the training uses the characteristics of several online learning applications.

\section{Conclusion}

Lecturers' capability in facing online learning is less than optimal. It was observable from the results of lecturers' evaluations during online learning during the Covid-19 pandemic. Lecturers' competence is still minimal in delivering lectures online. The younger lecturers did have skills in using digital media but because of a sudden policy changes, they are still in the early stage of adjustment that causes the lack of readiness in applying online learning during a pandemic covid-19. In other hands, senior lecturers are more heavily affected by the impact of distance learning because of the inability to use digital media. This resulted in monotonous learning methods. This factor causes the evaluation of lecturers' online learning performance results during the Covid-19 pandemic to be less effective.

Distance learning will become a permanent-hybrid model (blended learning) to meet the needs of higher education demands in the digital era. Therefore, the lack of and difficulties found in online learning during the Covid-19 pandemic previously should become a reference in finding the future online learning solutions. This article recommends that campuses take immediate action by conducting digital literacy training for lecturers, training online learning curriculum, preparing campus e-learning and training using several applications. These solutions are expected to contribute to the effectiveness of online learning in the future.

This study has some weaknesses in the survey results of lecturer data distributed using google form. The respondents are dominantly young lecturers so the data related to the inability of lecturers to use IT is less supportive because on average, they are proficient in using IT. There are only a few senior lecturers responded to the survey causing the descriptive results related on the age factors are less than the maximum. Thus, further research is needed to present broader and more in-depth lecturer performance results. Lecturers must be adaptive to online learning as soon as possible. Moreover, lecturers must be more creative and innovative in managing the learning environment so that student enthusiasm increases. Lastly, Campuses are expected to be able to support the implementation of online learning. They must always analyze the evaluations of both lecturers and students to find out deficiencies and measure the success rate of teaching and learning practice in higher education. 


\section{References}

[1] R. E. M. I. Putri;, "Learning From Home dalam Perspektif Persepsi Mahasiswa Era Pandemi Covid-19," Semin. Nas. Hardiknas, pp. 17-24, 2020, [Online]. Available: http://proceedings.ideaspublishing.co.id/index.php/hardiknas/article/view/3/3.

[2] K. Grabinski, M. Kedzior, and J. Krasodomska, "education sciences Embedding E-Learning in Accounting Modules : The Educators 'Perspective," 2020.

[3] P. Biologi et al., "Universitas Abulyatama Jurnal Dedikasi Pendidikan COVID-19: PENERAPAN PEMBELAJARAN DARING DI,” vol. 8848, no. 2, pp. 193-200, 2020.

[4] A. R. Riyanda, K. Herlina, and B. A. Wicaksono, "Evaluasi Implementasi Sistem Pembelajaran Daring Fakultas Keguruan dan Ilmu Pendidikan Universitas Lampung," J. IKRA-ITH Hum., vol. 4, no. 1, pp. 66-71, 2020, [Online]. Available: https://journals.upi-yai.ac.id/index.php/ikraithhumaniora/article/view/669.

[5] I. Tsani, R. Efendi, and S. Sufirmansyah, "Evaluasi kesiapan lembaga pendidikan tinggi Islam dalam menghadapi era digital," Ta'dibuna J. Pendidik. Islam, vol. 9, no. 1, p. 019, 2020, doi: 10.32832/tadibuna.v9i1.2604.

[6] A. Yudiawan, "BELAJAR BERSAMA COVID 19 : Evaluasi Pembelajaran Daring Era Pandemi di Perguruan Tinggi Keagamaan Islam Negeri , Papua Barat," vol. 6, no. 1, pp. 10-16, 2020.

[7] J. M. G. Nahdi, D.S., "Jurnal Cakrawala Pendas ANALISIS LITERASI DIGITAL CALON GURU SD DALAM PEMBELAJARAN BERBASIS VIRTUAL CLASSROOM DI MASA PANDEMI COVID-19," vol. 6, no. 2, pp. 116-123, 2020.

[8] W. Darmalaksana, R. Y. A. Hambali, A. Masrur, and Muhlas, "Analisis Pembelajaran Online Masa WFH Pandemic Covid-19 sebagai Tantangan Pemimpin Digital Abad 21," Karya Tulis Ilm. Masa Work From Home Covid-19 UIN Sunan Gunung Djati Bandung Tahun 2020, vol. 1, no. 1, pp. 112, 2020.

[9] U. A. Makassar, "Buku Pedoman Edukasi UIN Alauddin Makassar," in Pedoman Edukasi, 2019, p. 11.

[10] W. D. UGM, "Optimalisasi Pembelajaran Daring di Masa Pandemi _ Universitas Gadjah Mada." 2020.

[11] M. I. Mustofa, M. Chodzirin, L. Sayekti, and R. Fauzan, "Formulasi Model Perkuliahan Daring Sebagai Upaya Menekan Disparitas Kualitas Perguruan Tinggi," Walisongo J. Inf. Technol., vol. 1, no. 2, p. 151, 2019, doi: 10.21580/wjit.2019.1.2.4067.

[12] U. A. Chaeruman, "Alur Belajar: Meningkatkan Interaktivitas Pembelajaran Daring," Semin. Lokakarya Pembelajaran Daring di Perguru. Tinggi, no. September, pp. 1-10, 2017, doi: -.

[13] E. F. Artanti and A. Suddin, "Pengaruh Kompetensi, Komunikasi, Dan Kecerdasan Emosional Terhadap Kinerja Dosen Di Sekolah Tinggi Pariwisata Sahid Surakarta,” J. Manaj. Sumber Daya Mns., vol. 13, pp. 261-269, 2019.

[14] J. Miles, Matthew B., Huberman, A. Michael., Saldana, No TitleQualitative Data Analysisis; A Methods Sourcebook. 2017.

[15] A. Prajana et al., "Pemanfaatan Aplikasi Whatsapp dalam Media Pembelajaran di UIN Ar-Raniry Banda Aceh," Cybersp. J. Pendidik. Teknol. Inf., vol. 2, no. 2, pp. 38-45, 2018, doi: 10.5120/ijca2018918256. 